\title{
Thrombin-induced CCN2 expression as a target for anti-fibrotic therapy in scleroderma
}

\author{
Andrew Leask
}

Received: 7 November 2009/Accepted: 12 November 2009/Published online: 3 December 2009

(C) The Author(s) 2009. This article is published with open access at Springerlink.com

\begin{abstract}
Scleroderma (systemic sclerosis, SSc) is a fibrotic disease for which there is no therapy. CCN2 (connective tissue growth factor, CTGF) is a marker and mediator of fibrosis. Previously, it has been shown that thrombin induces CCN2 expression in fibroblasts. In a recent fascinating report, Bogatkevich et al. (Arthritis Rheum 60:3455-3464, 2009) show that dabigatran, an inhibitor of thrombin action, blocks the overexpression of $\mathrm{CCN} 2$ by scleroderma fibroblasts and reverses the contractile phenotype of these cells. These results strongly suggest that dabigatran may be a potential antifibrotic drug for the treatment of fibrosing diseases such as scleroderma.
\end{abstract}

Keywords CTGF. CCN2 - Scleroderma - Thrombin . Myofiroblast $\cdot$ Fibrosis

SSc is a prototypical multisystem disease with a significant fibrotic component; patients often die due to lung fibrosis (Varga and Abraham 2007). There is no therapy for SSc; however, recent studies have shown that, as for other fibroproliferative diseases, a particular type of differentiated fibroblast, termed the myofibroblast, contributes to scar formation in this disease (Chen et al. 2005). Myofibroblasts are characterized by an increased proliferative and contractile capacity and abundant expression of $\alpha$-smooth muscle actin ( $\alpha$-SMA), collagens, and other ECM proteins (Hinz et al. 2007). Overexpression of CCN2 is also considered to be

A. Leask $(\bowtie)$

CIHR Group in Skeletal Development and Remodeling, Division of Oral Biology, Department of Dentistry, Schulich School of Medicine and Dentistry, Dental Sciences Building,

University of Western Ontario,

London, ON, Canada N6A 5C1

e-mail: Andrew.leask@schulich.uwo.ca a key marker of fibrotic fibroblasts; the levels of CCN2 expression correlate well with the severity of fibrosis in SSc (Leask 2004; Dziadzio et al. 2005; Leask et al. 2009). Thus, targeting the action of the myofibroblast is essential for developing rational therapies for SSc. Of note, it is essential to remember that, in spite of the fact that in vitro the potent pro-fibrotic cytokine transforming growth factor $\beta$ (TGF $\beta$ ) induces $\alpha$-SMA expression and myofibroblast differentiation, blocking canonical TGF $\beta$ signaling does not affect the $\alpha$-SMA or CCN2 expression in scleroderma fibroblasts (Leask 2006; Chen et al. 2006).

When applied to lung fibroblasts, thrombin, a multifunctional serine protease and a key enzyme of blood coagulation that catalyzes the conversion of fibrinogen to fibrin (Green 2006), induces myofibroblast formation and CCN2 expression (Chambers et al. 2000; Bogatkevich et al. 2001). Dabigatran is a selective direct thrombin inhibitor that reversibly binds to thrombin and prevents the cleavage of fibrinogen to fibrin (Sorbera et al. 2005). In a recent study by Bogatkevich and colleagues, dabigatran blocked thrombin-induced myofibroblast differentiation, and suppressed $\mathrm{CCN} 2, \alpha$-SMA, and collagen overexpression by scleroderma fibroblasts.

Previously, it was shown that inhibition of endothelin-1, but not canonical TGF $\beta$ signaling, reverses the $\alpha$-SMA and CCN2 overexpression by SSc fibroblasts (Shiwen et al. 2004, 2007; Chen et al. 2006). Thrombin itself has been demonstrated to induce endothelin-1 (Lepailleur-Enouf et al. 2000). These data suggest that thrombin activity may be responsible for the overexpression of endothelin-1, $\alpha$-SMA and $\mathrm{CCN} 2$ in SSc fibroblasts and thus for the fibrosis observed in this disease.

This study suggests that dabigatran might prove to be a promising drug for the treatment of fibrotic conditions where there is thrombin overexpression. However, studies 
using additional in vivo preclinical models are required first, prior to conducting extensive clinical trials.

Open Access This article is distributed under the terms of the Creative Commons Attribution Noncommercial License which permits any noncommercial use, distribution, and reproduction in any medium, provided the original author(s) and source are credited.

\section{References}

Bogatkevich GS, Tourkina E, Silver RM, Ludwicka-Bradley A (2001) Thrombin differentiates normal lung fibroblasts to a myofibroblast phenotype via proteolytically activated receptor-1 and protein kinase C-dependent pathway. J Biol Chem 276:4518445192

Bogatkevich GS, Ludwicka-Bradley A, Silver RM (2009) Dabigatran, a direct thrombin inhibitor, demonstrates antifibrotic effects on lung fibroblasts. Arthritis Rheum 60:3455-3464

Chambers RC, Leoni P, Blanc-Brude OP, Wembridge DE, Laurent GJ (2000) Thrombin is a potent inducer of connective tissue growth factor production via proteolytic activation of protease-activated receptor-1. J Biol Chem 275:35584-35591

Chen Y, Shiwen X, van Beek J, Kennedy L, McLeod M, Renzoni EA, Bou-Gharios G, Wilcox-Adelman S, Goetinck PF, Eastwood M, Black CM, Abraham DJ, Leask A (2005) Matrix contraction by dermal fibroblasts requires TGFbeta/ALK5, heparan sulfate containing proteoglycans and MEK/ERK: insights into pathological scarring in chronic fibrotic disease. Am J Pathol 167:1699-1711

Chen Y, Shi-wen X, Eastwood M, Black CM, Denton CP, Leask A, Abraham DJ (2006) ALK5 (TGFß receptor type I) signaling contributes to the fibrotic phenotype of scleroderma fibroblasts. Arthritis Rheum 54:1309-1316
Dziadzio M, Usinger W, Leask A, Abraham D, Black CM, Denton D, Stratton R (2005) N-terminal CTGF is marker of fibrosis for the connective tissue disease scleroderma. QJM 98:485-492

Green D (2006) Coagulation cascade. Hemodial Int 10(Suppl 2):S2S4

Hinz B, Phan SH, Thannickal VJ, Galli A, Bochaton-Piallat ML, Gabbiani G (2007) The myofibroblast: one function, multiple origins. Am J Pathol 170:1807-1816

Leask A (2004) Transcriptional profiling of the scleroderma fibroblast reveals a role for CTGF in fibrosis. Keio J Med 53:74-77

Leask A (2006) Scar wars: is TGF $\beta$ the phantom menace in scleroderma? Arthritis Res Ther 8(4):213

Leask A, Parapuram SK, Shiwen X, Abraham DJ (2009) Connective tissue growth factor (CTGF, CCN2) gene expression: a potent clinical marker of fibroproliferative disease. J Cell Commun Signal 3:89-94

Lepailleur-Enouf D, Valdenaire O, Philippe M, Jandrot-Perrus M, Michel JB (2000) (2000) Thrombin induces endothelin expression in arterial smooth muscle cells. Am J Physiol Heart Circ Physiol 278:H1606-H1612

Shiwen X, Chen Y, Denton CP, Eastwood M, Renzoni E, Bou-Gharios G, Dashwood MR, duBois R, Black CM, Leask A, Abraham DJ (2004) Endothelin-1 promotes mechanoregulation and myofibroblast formation in fibroblasts through the ETA receptor via Akt/ PI3 kinase: implications for lung fibrosis. Mol Biol Cell 15:2707-2719

Shi-wen X, Renzoni EA, Kennedy L, Howat S, Chen Y, Pearson JD, Bou-Gharios G, Dashwood MR, du Bois RM, Black CM, Denton CP, Abraham DJ, Leask A (2007) Endogenous endothelin-1 signaling contributes to type I collagen and CCN2 overexpression in fibrotic fibroblasts. Matrix Biol 26:625-632

Sorbera LA, Bozza J, Castaner J (2005) Dabigatran/Dabigatran etexilate prevention of DVT, prevention of ischemic stroke, thrombin inhibitor. Drugs Future 30:877-885

Varga J, Abraham D (2007) Systemic sclerosis: a prototypic multisystem fibrotic disorder. J Clin Invest 117:557-567 